\title{
Surgical Complications RevealingNephrotic Syndrome Of Children At "Hopital Saint Jean De Dieu De Tanguieta" (Benin)
}

\author{
Séraphin Ahoui ${ }^{1 \star}$, Montcho Adrien Hodonou ${ }^{1}$, Roméo Haoudou ${ }^{2}$, Evariste Eteka ${ }^{1}$, Romaric Tobome ${ }^{2}$, Hubert Charlemagne \\ Egoulety $^{2}$ and Giambastiani Priuli ${ }^{2}$
}

${ }^{1}$ Faculty of Medicine, University of Parakou, Benin

${ }^{*}$ Corresponding author

${ }^{2}$ Tanguiéta District Hospital

\author{
Ahoui Séraphin, Faculty of Medicine, University of Parakou, Benin, BP 02 \\ Parakou, Bénin
}

Submitted: 06 May 2020; Accepted: 11 May 2020; Published: 22 Sept 2020

\begin{abstract}
Background:Thromboembolic and infectious complications of nephrotic syndrome are powerfuland canbefunctional or life threatening. Surgical complications are rare, hence the interest of our work which aimed to study the therapeutic and evolutionary clinical aspects of the surgical complications of the children's nephrotic syndrome at "Hopital Saint Jean De Dieu De Tanguieta" (Benin).
\end{abstract}

Methods: This was a prospective case study of children with complicatednephrotic syndrome followed at "Hopital Saint Jean De Dieu De Tanguieta" (Benin) fromOctober 2016 to December 2018.

Results: We reported two cases, all male. Before surgical complications the symptoms were dominated by an oedema syndrome lasting for each of them on averageeightmonths. Surgical complications thatrevealednephrotic syndrome were a spontaneous amputation of the right foot due to arterialthrombosis in a seven-year-old boy and a necrotizingfasciitis of the left foot in a 10-year-old child.The nephrotic syndrome wasidiopathic and the cares werebothsurgical and medical. Nephrotic syndrome wascorticosensitivewith a goodevolution in five months.

Conclusion: These two cases teach that any childhoodoedema syndrome must bequicklyexplored for appropriated management to avoidtheseserious complications and aftereffects.

Keywords: Nephrotic Syndrome, Foot Amputation, Necrotizing Fasciitis, Thrombosis, Child, Tanguieta

\section{Introduction}

Nephrotic syndrome is a glomerulardisease. His diagnosis is biological. The majority of diagnoses $85 \%$ of anatomopathological cases in children 1 to 10 years of ageis made of minimal change glomerulopathywhich areoftencorticosensitive [1]. Nephrotic syndrome has several complications, the strongest one are thromboembolism, infections and kidneyfailure. [1]. We report a case of nephrotic syndrome revealed by a spontaneous amputation of the right foot ina seven-year-oldchild due to arterialthrombosis and another one revealed by a necrotizingfasciitis of the left foot in a 10-year-old child. These are two rare surgical complications thatrevealednephrotic syndrome at 'Hopital Saint Jean De Dieu De Tanguieta".

\section{Methods}

This was a prospective case study of children with complicated nephrotic syndrome seenrespectively at "'Hopital Saint Jean De Dieu De Tanguieta" (Benin) in October 2016 and May 2017 and followed until December 2018. The management of kidney disease at "Hopital Saint Jean De Dieu De Tanguieta" isfunded.

\section{Results}

\section{Observation 1}

The seven-year-oldchild A. M., with no knownpathologicalhistory, isadmitted to the emergency department of ' Hopital Saint Jean De Dieu De Tanguieta", in October 2016, for the treatment of a spontaneous amputation of the right foot at home. The onset of the diseasewas about a yearsinceand marked by an oedema syndrome, whichthen spreads to anasarca. That led to consultatraditionalhealer and afterin healthcare centre withoutanyimprovement. The evolutionwasmarked by aphtoses, fever, pain of the lower right limb and necrosis of the toes of the right foot thenreaching the entire foot and lower middle part of the right leg. During treatment with indigenate therapy, the right foot wasspontaneouslyamputated at home. That motivatedhis admission to the hospital. The clinicalexaminationuponhisadmission noted a generalpoor condition, blood pressure at $130 / 65 \mathrm{~mm} \mathrm{Hg}$, a temperature at $36.8 \mathrm{C}$, a heart rate at 82 beats per minute and a body mass index at $19.5 \mathrm{~kg} / \mathrm{m} 2$ (height at $1.05 \mathrm{~m}$ and weight at $20 \mathrm{~kg}$ ). The popliteal pulses one right and leftfeetwere good. Edematous-ascitic 
syndrome and clinicalanemiawerenoted. The biological balance showed: 24-hour proteinuria at $107 \mathrm{mg} / \mathrm{kg}$, protidemia at $34 \mathrm{~g} / \mathrm{l}$, albuminemia at $14 \mathrm{~g} / 1$, bloodsugarlevel at $0.89 \mathrm{~g} / 1$, urea $0.30 \mathrm{~g} / 1$, creatininemia $11.6 \mathrm{mg} / \mathrm{l}$, Total cholesterol range and HDL cholesterol rangewere $2.86 \mathrm{mg} / \mathrm{l}$ and $1.75 \mathrm{mg} / \mathrm{l}$, respectively. Natremiawasobserved at $126 \mathrm{mEq} / \mathrm{l}$, kaliemia at $3.60 \mathrm{mEq} / \mathrm{l}$, chloremia at $96 \mathrm{mEq} / \mathrm{l}$. The hemogramwas in favour of microcyticanemiawithhemoglobinlevels at $10.6 \mathrm{~g} / \mathrm{dL}$ and leukocytosis at $12800 \mathrm{G} / \mathrm{l}$. The C ReactiveProteinwas $47 \mathrm{mg} / \mathrm{l}$. The serologies of Hepatitis $\mathrm{B}$ and $\mathrm{C}$ and HIV viruseswerenegative. Doppler ultrasound of the lowerlimbspointed outarterialthrombosis of the right leg. The diagnosiswas an idiopathic nephrotic syndrome of the childwithsevere infectious andthromboembolic complications resulting in a dry right foot gangrenewithspontaneous amputation. Treatmentwas on the one hand surgical to have a heathystumpin 2 times, and medical on the other hand withhygienicmeasures. Pictures 1 and 2 show the aspects of the pelviclimbs and gangrene of the right foot as soon as heisadmittedat "Hopital Saint Jean de Dieu de Tanguieta".

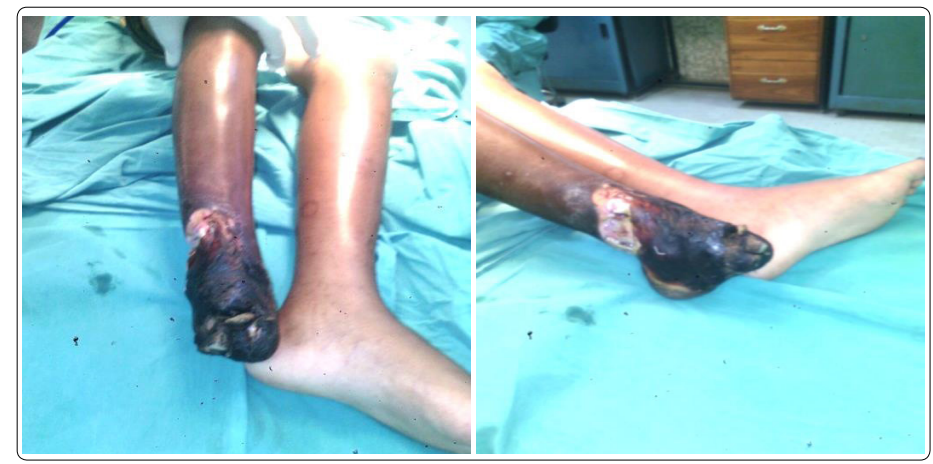

Pictures 1 and 2 show the aspects of the pelviclimbs and gangrene of the right foot upon admission to "Hopital Saint Jean De Dieu De Tanguieta"

\section{Observation 2}

S, M. 10 yearsold, Beninese, wasadmitted to the emergency department of 'Hopital Saint Jean De Dieu De Tanguieta", in May 2017, for an ulceration of hispelviclimbassociatedwithoedema syndrome. The onset of the diseaseis about sevenmonthssince and marked by a renaltype oedema. The parents had used traditional drugs without success. The clinicalexamination on admission noted a generalpoor condition, blood pressure at 120/75 mm Hg, a temperature at $37.9 \mathrm{C}$, a heart rate at 112 beats per minute and a body mass index at $18.7 \mathrm{~kg} / \mathrm{m} 2$ (height at $1.35 \mathrm{~m}$ and weight at 34 $\mathrm{kg}$ ). The pulse of the right pelviclimbwaswellperceived. An ulceration of the left foot, leg and thigh. The biological balance showed: 24-hour proteinuria at $217 \mathrm{mg} / \mathrm{kg}$, protidemia at $28 \mathrm{~g} / \mathrm{l}$ an albuminemia at $12 \mathrm{~g} / \mathrm{l}$, bloodsugar at $0.89 \mathrm{~g} / \mathrm{l}$, urea $0.30 \mathrm{~g} / \mathrm{l}$, creatininemia $11.6 \mathrm{mg} / \mathrm{l}$. Total cholesterol range and HDL cholesterol rangewere $2.90 \mathrm{mg} / \mathrm{l}$ and $1.20 \mathrm{mg} / \mathrm{l}$, respectively. Natremiawasobserved at $122 \mathrm{mEq} / 1$, kaliemia at $3.80 \mathrm{mEq} / 1$, chloremia at $102 \mathrm{mEq} / 1$. The hemogramwithhemoglobin at $11.2 \mathrm{~g} /$ $\mathrm{dl}$, leukodytosis at $13000 \mathrm{G} / \mathrm{l}$ and $180 \mathrm{G} / 1$ of platelets. The serologies of Hepatitis B and C and HIV viruseswerenegative. The diagnosiswas an idiopathicnephrotic syndromecomplicatedby a necrotizingfascitis of the leftleg and thigh. Treatmentwas on the one hand surgical by necrosectomy of the leftpelviclimb, and medical on the other hand withhygienicmeasures.

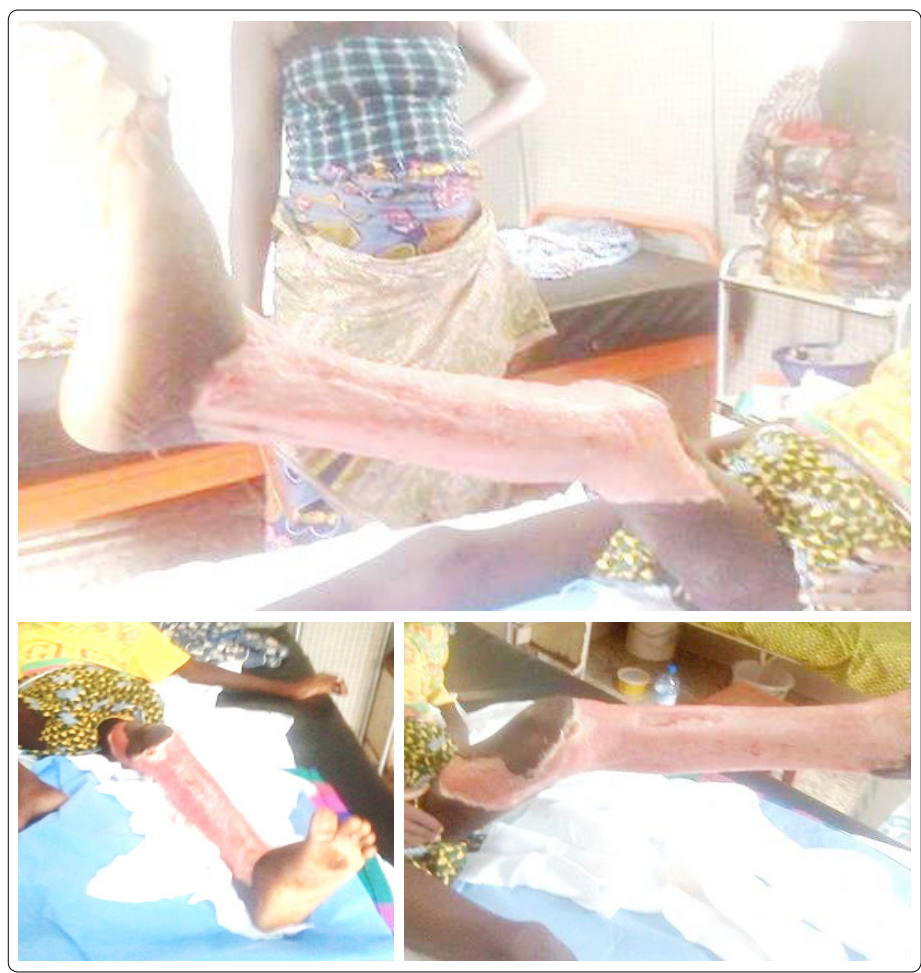

Pictures 3,4 and 5 show aspects of the leftpelviclimb.

For both patients, medicaltreatmentwascorticosteroidtherapyfor a five-monthperiod by progressive cessation afternegativation of proteinuria and a balance of protidemia and albuminemia. A second treatment due tocortico steroid therapy was instituted with the intake of potassium, calcium, and proton pumpinhibitor. Anti protein uria treatment was instituted, taking low doses of ACE Inhibitor. Also they had received heparin and then platelet anti aggregant. Against the infections theyhad been treated with ceftriaxone, metronidazole. Theytookstatin and diuretics.

As hygienic-dietarymeasures, therewasadietwithoutsugar, low in salt and fat, but rich in calcium and potassium.

The evolutionundermedicaltreatment has been goodwith an improvement in the clinical and para-clinical condition. The patient isasymptomaticafter 5 months of corticosteroidtherapywith a progressive stop. The post-operativefollow-upswere simple. The seven-year-oldwasfittedwithhis right foot. Pictures 4 and 5 show the stumphealingbeforedeparture.

\section{Discussion}

The symptoms of nephrotic syndrome ispolymorphic and its diagnosis is biological. Complications are various [1]. Thromboembolic complications are found in $10-40 \%$ of cases of nephrotic syndrome [2]. Arterialthrombosisrepresent $19-27 \%$ of cases of thromboembolic complications. Amongsmallchildren population, thromboticphenomena are more severethan in adults, readilyreachingarterialterritories and are allowedby episodes of extracellulardehydration andhypercoagulability. Neglect and delay in care can cause damages. In ourseries, the children were admitted to the hospitalwhen complications occurand not for the management of nephrotic syndrome. Apartfromgangrene and necrotizingfasciitis there are stilldangerous complications such as 
pulmonary embolisms, strokes, thrombosis of the kidneyvessels [1]. The various abnormalities of hemostasis have been describedduring the NephroticSyndrome and mayexplainthis high incidence of thomboebolicdiseases. High levels of various clotting factors (fibrinogen, factors V, VIII, XIII) are frequently found during nephrotic syndrome [1]. The elevation of fibrinogenis the most consistent anomaly [1]. Delays in management lead to serious complications but if the NSiscorticosensitivelikethis onethereishope. Ignorance of the clinical picture promotes treatment with herbal medicine and the real treatmentis postponed and doneonly at the complication stage.

\section{Conclusion}

Thromboembolic and infectious complications of nephrotic syndrome remain powerful. Earlydiagnosis and appropriated treatment could preventthesecomplications.Itisnecessarytoraisecommunityawareness about the management of oedema syndrome.

\section{References}

1. Niaudet P (2008) Syndrome néphrotique chez l'enfant. EMC 2008: 149-161.

2. Kerlin BA, Ayoob R, Smoyer WE (2012) Epidemiology and pathophysiology of nephrotic syndrome-associatedthromboe mbolicdisease. Clin J Am Soc Nephrol7:513-520.

3. LilovaMI,Velkovski IG, Topalov IB (2000) Thromboembolic complications in childrenwithnephrotic syndrome in Bulgaria (1974-1996). PediatrNephrol15:74-78.

4. Joseph Loscalzo (2013) VenousThrombosis in the Nephrotic Syndrome.Clinical implications of basic research NEnglJMed 10 : 956-958.
Copyright: (C2020 Ahoui Séraphin, et al. This is an open-access article distributed under the terms of the Creative Commons Attribution License, which permits unrestricted use, distribution, and reproduction in any medium, provided the original author and source are credited. 